\title{
Fair Use and Statutory Reform in the Wake of Eldred
}

\author{
William F. Patry $\dagger$ and Richard A. Posner $\ddagger$
}

\section{INTRODUCTION}

The Supreme Court in Eldred v. Ashcroft $t^{\prime}$ upheld the constitutionality of the Sonny Bono Copyright Term Extension Act (CTEA). ${ }^{2}$ The Court did this not because it believed it wise to tack 20 years onto all existing copyrights, as well as to copyrights for new works, but because it did not believe that Congress had exceeded its constitutional authority in doing so. The Court did not deny that extension would create problems; one of these is our concern in this Article. It is the problem of obtaining licenses to reproduce old works of limited commercial value. The retroactive feature of the CTEA is keeping many of those works from falling into the public domain, where they could be copied and disseminated without the need to locate and negotiate with the owner of a copyright. We suggest that the problem can be solved either by continued evolution of the judicially shaped doctrine of fair use or by a modest amendment to the Copyright Act. We discuss both possible solutions, but begin with a review of the problem.

Copyright (O 2004 California Law Review, Inc. California Law Review, Inc. (CLR) is a California nonprofit corporation. CLR and the authors are solely responsible for the content of their publications.

$\dagger \quad$ William F. Patry is a partner in Thelen Reid \& Priest, LLP.

$\ddagger \quad$ Richard A. Posner is a judge of the U.S. Court of Appeals for the Seventh Circuit and a senior lecturer at the University of Chicago Law School. The authors thank Gavin Martinson and Liss Palamkunnel for their very helpful research assistance.

1. 537 U.S. 186 (2003). Subsequently, two district courts have rejected challenges to the constitutionality of the 1994 resurrection of certain works from the public domain. See Luck's Music Library, Inc., v. Ashcroft, 2004 U.S. Dist. LEXIS 10626 (D.D.C. June 10, 2004); cf. Golan v. Ashcroft, 310 F. Supp. 2d 1215 (D. Colo. 2004) (dismissing as to some claims but permitting others to go forward).

2. Pub. L. No. $105-298, \S 102$ (b), (d), 112 Stat. 2827-28 (1998) (amending 17 U.S.C. $\S \S 302$, 304) [hereinafter CTEA]. 


\section{The Problem}

The CTEA gives the author (or the author's assignee), a copyright term that lasts until 70 years after the author's death, when the author is a natural and known person and the work was created after December 31, $1977 .{ }^{3}$ If the author is a corporation or other institution holding copyright under the work-made-for-hire doctrine, or is anonymous or pseudonymous, the term is the shorter of 95 years from first publication or 120 years from creation. ${ }^{4}$ Works published before January 1, 1978, thus have a maximum possible ${ }^{5}$ term of 95 years from the date of first publication, with the result that works first published between 1923 and 1977, which prior to the enactment of the CTEA would have begun to fall into the public domain in 1998, will now remain under copyright until the end of 2018 at the earliest and until 2072 at the latest (longer, if Congress extends the term of copyright again). ${ }^{6}$ In the case of copyrighted works that are old and lack the commercial cachet of a Mickey Mouse or Rhapsody in Blue, it may be difficult to ascertain the owner of the copyright, and, once the owner is ascertained, the time and expense required to negotiate a license from him may be disproportionate to the value of the work to the would-be reproducer of it.

The problem would be less serious were it not for the fact that the Copyright Act of $1976^{7}$ had, as required by the Berne Convention, jettisoned the requirement of renewal after a relatively short fixed term. ${ }^{8}$ Not only did renewal provide notice of subsisting copyright, but experience with the requirement of renewal had established that works that have no commercial value are unlikely to be renewed, ${ }^{9}$ thus increasing the size of the public domain. To dispense with the requirement of renewal and extend the copyright term is to strike a double blow at the public domain. As explained in the petitioners' opening brief to the Supreme Court in the Eldred case:

Between 1923 and 1942, there were approximately 3,350,000 copyright registrations. Approximately $425,000(13 \%)$ of these were renewed. The Congressional Research Service estimated that of these, only $18 \%$, or approximately 77,000 copyrights, would

3. 17 U.S.C. $\$ 302(a)$.

4. 17 U.S.C. $\S 302$ (c).

5. We say "possible" because to obtain this protection for domestic works first published before January 1,1964 , the copyright owner was required to file a timely renewal. 17 U.S.C. $\$ 304$ (1978, 1992, 1998).

6. 17 U.S.C. $\$ 304(1998)$.

7. Pub. L. No. 94-553; 90 Stat. 2541, 2598.

8. Berne Convention for the Protection of Literary and Artistic Property, Paris Act, art. 5(2) (1971).

9. For the evidence, see William M. Landes \& Richard A. Posner, The Economic Structure of Intellectual. Property Law 237-38 (2003). 
constitute "surviving works" ... Today, the proportions would be far more significant, since there is no "renewal" requirement that moves over $85 \%$ of the works copyrighted into the public domain. Under current law, 3.35 million works would be blocked to protect $77,000 .^{10}$

The brief of the Eldred petitioners gave a number of concrete examples of the difficulty faced by publishers of old works. ${ }^{11}$ It pointed out, for example, that prior to the CTEA,

Dover Publications, a large-scale publisher of high-quality paperback books, including fiction and children's books[,]... had planned to republish a number of works from the 1920's and 1930's, including The Prophet by Kahlil Gibran and The Harp-Weaver by Edna St. Vincent Millay. [The CTEA] has delayed the entry of these works into the public domain by 20 years. ${ }^{12}$

Other publishers who had been planning to release new sheet music of works by Richard Strauss, Bela Bartok, and Maurice Ravel; genealogy; historical maps; local and county histories; and even books on the history and traditions of golf were also stymied by the CTEA.

Moviecraft, Inc. is a ...commercial entity that depends upon old film for its business. Much of this film is "orphaned" because current copyright holders cannot be identified, and all of it is now decaying because of the unstable properties of nitrate-based film and even so-called "safety" film. Moviecraft restores these old films when they pass into the public domain, but under [the Sonny Bono Act] no films will pass into the public domain for 20 years. ${ }^{13}$

And there is Eldred himself, a noncommercial online publisher of both existing works and also new derivative ones.

In 1995, Eldred founded an Internet-based press, Eldritch Press. Eldritch Press creates free versions of public domain works for the World Wide Web, as well as works for which he has obtained permission. These works are coded in the hypertext markup language (HTML) that underlies the Web. Eldred's press specializes in collections of [Nathaniel] Hawthorne, Oliver Wendell Holmes, Sr., and Henry James, among others.

Eldred's creations are both copies and derivative works. By using the technology of the Internet, he is able to build texts that are

10. Brief for Pet'rs at 7, Eldred v. Ashcroft, 537 U.S. 186 (2003) (No. 01-618) (citations omitted).

11. See id. at 3-7.

12. Id. at 3 .

13. Id. at 4 (citations omitted) 
available freely around the world. By integrating search technologies and links, his texts enable students and scholars to study these works in ways that would be impossible with printed books. In this sense, Eldred is building a library of public domain works, but with a technological capacity far exceeding that of the ordinary library. Unlike a library, however, every part of an online collection is potentially regulated by copyright law. Because each posting of a work is technically a "copy," each posting is within the reach of the Copyright Act. ${ }^{14}$

A related example involves Brewster Kahle, who, through his "Internet Archive," has stored copies of the entire Internet over the past 6 years. With Rick Prelinger, Kahle has also built an archive of public domain movies which will make film available in a digital form to viewers and filmmakers around the world. The technical capacity of this archive is limited only by the number of machines linked to the network. But the regulatory constraints of copyright cannot be so easily overcome. The copyright owners of many of these films cannot even be identified. Their work thus cannot be made available on the Internet. ${ }^{15}$

There are many other examples of the problem besides those flagged by the Eldred petitioners. Here are just two. Belgrave House reissues as e-books popular fiction that has gone out of print. Neff Rotter of Belgrave House, asked whether his company had been affected by Eldred $v$. Ashcroft, replied: "Yes. I'd like to make e-books of Georgette Heyer Regencies, but now they won't come out from copyright for many years."16 Modern Library Paperbacks, which publishes books online, was hurt when the CETA continued the copyrights of works such as The Great Gatsby and Mrs. Dalloway. David Ebershoff, the publishing director, remarked that before the CTEA, " $\mathrm{t}]$ he first thing you'd do in the classics publishing was keep a list - a rolling schedule of what was going into the public domain. ... That was item No. 1. Now it's not only not item No. 1; it's not an item" since no copyrights will expire until 20I8. ${ }^{17}$

A possible solution to the problem that the foregoing examples illustrate is simply an intelligent interpretation and administration of the fair use defense to copyright infringement. Recognition of this point has been occluded both by widespread misunderstanding of the scope of the defense and by the asymmetrical stakes of copyright owners and public-domain publishers (a term we use broadly, to denote all individuals and

14. Id. at 5 (citations omitted).

15. Id. at 6 (citations omitted).

16. Where no source is given for information in footnotes, the source is a personal communication to one of the authors or to a research assistant, or a corporate website.

17. See Bill Goldstein, "Publishers Give Classics a Makeover," N.Y. TIMEs, Feb. 10, 2003, at C9. 
organizations, whether or not commercial, that engage in the serious dissemination of public-domain works) in copyright litigation. ${ }^{18}$

\section{II}

\section{A Fair Use Solution}

\section{A. Fair Use: Common Law and Statutory}

The fair use defense allows the copying of parts, and sometimes the whole, of copyrighted works without the authorization of the copyright owner. ${ }^{19}$ At first glance this may seem a species of communism, as if someone had a legal right to lounge in your backyard without your permission. But there are two pertinent differences between physical and intellectual property. The first is that using someone else's physical property necessarily interferes with the owner's right to the use of it because two people cannot occupy the same physical space at the same time; if some stranger is lying in your hammock, you cannot lie there at the same time. The second pertinent difference is that it is usually straightforward to negotiate a sale or rental of physical property.

In those rare cases in which transaction costs are prohibitive, the owner of physical property may lose his right to exclusive control through the operation of such doctrines of property law as adverse possession, abandonment, private and public necessity, nuisance, and eminent domain. Those cases are exceptional; their counterparts in intellectual property are not. Copying a brief passage from a book does not interfere with the copyright owner in a way that squatting in his house would, though copying the entire book and then selling the copy in competition with the copyright owner's licensees would. And negotiating for a right to use intellectual property tends to be more cumbersome than the corresponding negotiations over physical property, in part because intellectual property is more difficult to identify (because it is intangible) than physical property and in part because the cost to the copyright owner and the value to the would-be copier usually are slight, a point again illustrated by the copying of a brief passage. So it is not really a surprise, and not inconsistent with the scope of property rights in land and chattels, that there should be a much broader fair use rigbt in the intellectual property domain. The difference is rooted in economic differences between physical and intellectual property that make it perilous to move too quickly from one to the other, as when even trivial copying is denounced as "theft" by analogy to the undoubted principle that theft of physical property is not excused by the fact that only a small amount of the owner's property is taken.

18. By "serious" dissemination, we mean to exclude individual file-sharing, as by users of Napster-type services, and other purely personal distribution of expressive works.

19. 17 U.S.C. $\$ 107$. 
All this is not to suggest that there should be a right to unlimited copying of an expressive work without the authorization of the copyright owner. That would be the undoing of copyright and would make it difficult and in some cases impossible for authors of expressive works to recoup their expenses in creating the work, especially in an era of very rapid, cheap, and accurate copying brought about by digitization. To preserve copyright and protect the legitimate interests that it serves, the right conferred by the fair use defense to infringement must be of limited scope.

The fair use defense was developed by the federal courts long before it was given statutory recognition in section 107 of the Copyright Act of $1976 .{ }^{20}$ And despite that enactment it remains a judicial doctrine. The closest analogy is to those provisions of the Taft-Hartley Act and ERISA that have been interpreted to grant common law rulemaking authority to the federal courts to fill spaces left by Congress. ${ }^{21}$ Section 107 in effect tells the courts to continue doing what they had been doing for more than a century.

Section 107 states that "the fair use of a copyrighted work ... for purposes such as criticism, comment, news reporting, teaching ... scholarship or research, is not an infringement of copyright,",22 and to decide whether a particular use is fair,

[T] he "factors to be considered [by the court] shall include (1) the purpose and character of the use, including whether such use is of a commercial nature or is for nonprofit educational purposes; (2) the nature of the copyrighted work; (3) the amount and substantiality of the portion used in relation to the copyrighted work as a whole; and (4) the effect of the use upon the potential market for or value of the copyrighted work. ${ }^{23}$

Factor (1) is misleading in declaring a preference for noncommercial educational uses, since most expressive activity is commercial and so is most fair use copying. Factor (2) is empty; what does "nature of the copyrighted work" mean? Factor (3) is misleading, as we shall see, insofar as it might be read to imply that it is never fair use to copy an entire copyrighted work. And factor (4), besides failing even to hint at a quantum of harm that might either justify or defeat a fair use defense, fails to distinguish between a use that impairs the potential market for the copyrighted work by criticizing it

20. See, e.g., West Publ'g Co. v. Edward Thompson Co., 169 F. 833 (C.C.E.D.N.Y. 1909), modified on appeal, 176 F. 833 (2d Cir. 1910); Simms v. Stanton, 75 F. 6 (C.C.N.D. Cal. 1896); Lawrence v. Dana, 15 F. Cas. 26 (C.C.D. Mass. 1869) (No. 8,136); Story v. Holcombe, 23 F. Cas. 171 (C.C.D. Ohio 1847) (No. 13,497); Folsom v. Marsh, 9 F. Cas. 342 (C.C.D. Mass. 1841) (No. 4,901).

21. See Franchise Tax Bd. v. Const. Laborers Vacation Trust, 463 U.S. 1, 24 n.26 (1983); Textile Workers Union v. Lincoln Mills, 353 U.S. 448 (1957).

22. 17 U.S.C. $\$ 107$.

23. Id. 
from a use that impairs the copyrighted work's market or value by free riding on the work.

But all this is by the by, for what is important from the standpoint of understanding how the doctrine of fair use continues to be understood and applied is that the four statutory factors are expressly illustrative rather than controlling, that their weight is not specified, and that the purposes of the defense in light of which its contours are to be determined are left open-ended ("purposes sueh as"). ${ }^{24}$ All section 107 really amounts to in practieal terms is confirmation that the courts are entitled to allow in the name of fair use a certain undefined amount of unauthorized copying from copyrighted works. This may seem an unsatisfactory solution to the problem of defining fair use, and indeed the uncertain contours of the defense raise serious problems, as we shall see. But the defense has two redeeming features from the perspective of trying to solve the problem flagged by the Eldred brief. The first is that like most judge-made doctrines, the fair use defense is flexible. Judges made it and judges can adapt it to changed conditions, and CTEA has changed the conditions under which public domain publishers operate, as we have seen.

Interest-group pressures are a second consideration in favor of a judicially contoured fair use defense because such pressures play a greater role in legislation than adjudication, especially at the federal level, where judges have secure tenure. And because the interest-group pressures exerted by copyright owners and by public-domain publishers are asymmetric, the pressures for and against an expansive conception of copyright (and a concomitantly diminished scope for a fair use defense) do not cancel out. The reason for the asymmetry is the following: a public-domain publisher cannot prevent the copying of the works he publishes and therefore cannot hope to obtain a supracompetitive return. But copyright law enables the copyright owner to prevent anyone from competing against him by selling identical copies of the copyrighted work, and so if the work is popular he will be able to obtain a supracompetitive return. As a result of this difference in their relation to competition, copyright owners have more to lose in financial terms from an expansive fair use defense than public-domain publishers have to gain from it. We can expect this asymmetry to weigh heavily against legislative recognition of a generous defense.

We are, however, concerned by the inclination of some judges to view their role in the copyright system as enforcers of any claims copyright owners bring, no matter how extravagant the claim and how beneficial the unauthorized copying. This view of copyright is a problem not only for our proposal but for copyright in general. Recognition that the public benefits

24. See Harper \& Row, Publishers, Inc. v. Nation Enters., 471 U.S. 539, 561 (1985) (citing William F. Patry, The Fair Use Privilege in Copyright LaW 477 n.4 (1 st ed. 1985)). 
from certain unlicensed uses is essential and should be acknowledged, not rhetorically but in practice through generous interpretation of fair use.

\section{B. The Scope of Fair Use}

So the fair use defense permits some unauthorized copying of copyrighted works. But how much? Enough to solve the problem that the CTEA in conjunction with the earlier abolition of the renewal requirement has created? To answer these questions, we must examine the considerations that animate the fair use doctrine, as they also indicate its limits. ${ }^{25}$

The clearest case for the defense is where there is no harm, or even significant benefit forgone, to the copyright owner from granting a license, but precisely because the stakes are slight the cost of negotiating a license would be prohibitive. An example is where the copier wants to quote only a brief passage. In such a case the fair use privilege confers a clear benefit on the copier without harming the copyright owner. It imposes no out-ofpocket cost on the copyright owner and it "deprives" him of a benefit (that is, imposes an opportunity cost on him, a loss of potential revenue) that transaction costs would in any event prevent him from receiving. The copier is neither a firm selling copies nor a potential purchaser of copies and so his projected use affects neither the supply of copies nor the demand for them. As we will note in Part III, the law clearly recognizes a fair use defense in such cases.

It might seem that, if the copying does not harm the copyright owner, there would be no need for a fair use privilege to deal with such cases because he would be happy to grant a license gratis. There are several reasons to doubt this. The first is that, contrary to the assumption in the preceding paragraph, the owner of the copyright might be able to extract a fee from the would-be copier, though this would be a pure windfall in a case-the case of particular concern in the wake of the Eldred decision-in which the copyright was in its extension term, that is, was still in force only by virtue of Congress's having added 20 years to the term of all existing copyrights. Any receipt by a copyright owner during the extension term is a windfall because the anticipation of it could not have figured in his decision whether to create the work in the first place; that is, it could not have figured in his calculation of whether he could recoup his expenses before the copyright expired.

Second, many copyright owners, concerned with the vague contours of the fair use privilege, are reluctant to consent to any copying, lest their consent become a precedent for an expansion of the privilege or for a right of copying in general. As is apparent from the rampant file-sharing of popular music, many consumers do not take copyright law seriously and

25. See Landes \& Posner, supra note 9, at ch. 4. 
may therefore be prone to interpret fair use in extravagant terms if given any excuse to do so.

Third, a copyright owner might worry that his consent to copy would be abused. This is a particular concern in a dual fair use/infringement setting, such as that presented by the Sony Betamax case. ${ }^{26}$ The Supreme Court held that the use of the Betamax video recorder for time shifting, that is recording free (to the viewer) television programming for viewing at a more convenient time, was fair use because it enlarged the audience for television programs; but the Betamax was also used to fast forward through commercials, which impaired the value of the program to the copyright owner.

Fourth, a copyright owner might simply not want to be bothered with announcing a right of copying and spelling out the limitations on the right. It is much easier to say, "no copying without my permission"-and we shall see that some publishers and other copyright owners say just that.

The Betamax case illustrates another point that bears on the problem of old copyrighted works of limited commercial value. The copying allowed in that case in the name of fair use was the copying of entire works, not brief, or for that matter any, excerpts. The relevance of this is, of course, that Eldred and the other publishers of old works want to publish entire works, not excerpts. That fair use can authorize the copying of entire works is further illustrated by a recent case involving Beanie Babies. ${ }^{27}$ As a marketing gimmick, Ty, the manufacturer, deliberately creates a shortage of each Beanie Baby by charging a very low price and not producing enough copies to clear the market at that price. As a result, a secondary market is created that gives widespread publicity to Beanie Babies. When the defendant, PIL, published the Beanie Babies Collector's Guide in 1998, some Beanie Babies were selling in the secondary market for thousands of dollars, though others were selling for little more than their original purchase price of $\$ 5$ or so. The vastness of the range created a demand for collectors' guides.

Although Ty does not sell photographs of Beanie Babies, such photographs were either unauthorized reproductions or unauthorized derivative works, and in either case prima facie infringements of Ty's copyrights if made without Ty's consent. PIL's books included photographs of the entire line of Beanie Babies. The court held, however, that whether this copying was privileged as a fair use was a contestable issue. The court pointed out that because Ty had licensed the publication of collectors' guides that

26. Sony Corp. of America v. Universal City Studios, Inc., 464 U.S. 417 (1984).

27. Ty, Inc. v. Publ'ns Int'l Ltd., 292 F.3d 512 (7th Cir. 2002). One of the authors (Posner) wrote the opinion in Ty; another (Patry) was counsel to one of the parties. The discussion in the text summarizcs the opinion without cxpressing a view of the merits of the case, which is still pending on remand from the court of appeals' decision. The specific issue discussed in this Article, namely the problem of publication of old copyright works, is unrelated to the issues in the $T y$ litigation. 
contained photos of all the Beanie Babies, a competitor forbidden to publish photos of the complete line could not compete and the result of such a prohibition would therefore be to give Ty a monopoly of Beanie Babies collectors' guides, a monopoly that, the court emphasized, Ty could use to suppress criticism of particular Beanie Babies. ${ }^{28}$

Comparable to the time shifting involved in the Sony Betamax case is "space shifting," as by MP3.com's former "Beam It" and "Instant Listening" features of its My.Mp3.com service. ${ }^{29}$ MP3.com made server copies of sound recordings and placed them in an Internet-accessible database but allowed access to them only if the person seeking access proved that he possessed the $C D$ version of the recording. ${ }^{30}$ The service enabled music enthusiasts to listen to "their" recordings when they were not at home, and since it presupposed ownership of the CD the negative impact on the recording industry was minimized. Although a district court rejected the analogy to time shifting, ${ }^{31}$ the rejection is inconsistent with Sony's holding with respect to time shifting. The decision contains only a perfunctory analysis of fair use; the judge appeared to be more interested in punishing a perceived Internet "cowboy" than in applying the doctrine of fair use flexibly to a new environment. A narrower ground for the decision, argued but ignored by the judge (perhaps because the record did not contain evidence to support it), would have been that the defendant's method for requiring that its customers "prove" that they owned the CDs containing the music they wanted to download was lax. ${ }^{32}$

Now obviously the considerations that moved the courts to allow copying of whole works in Sony and Ty, and maybe should have done so in the MP3.com case as well, are different from those that would support a fair use privilege for copying old works; their significance is only in demonstrating the breadth of the fair use doctrine and, specifically, that it can

28. Id. at 521 .

29. UMG Recordings v. MP3.com, Inc., 92 F. Supp. 2d 349, 350 (S.D.N.Y. 2000)

30. Id.

31. MP3.com, Inc., 92 F. Supp. 2d at 351

32. See In re Aimster Copyright Litig., 334 F.3d 643, 653 (7th Cir. 2003). Two features of MP3.com's servicc were at issue, "Beam It" and "Instant Listening." MP3.com, Inc., 92 F.Supp.2d at 350. With Instant Listening, MP3.com directed the purchaser to an on-line site in order to purchase a copy. But rather than wait until the physical $C D$ was shipped, the purchaser could have the $C D$ streamed to her from a server copy that MP3.com had already made. There was no problem of verification of the Instant Listening service, because one purchased the copy via MP3.com's referral. But with Beam 1t, you had to verify that you had already purchased a copy, and you got a password to access your cyberspace "locker" account from which the CD was streamed to you via MP3.com's server copy. And here there were two verification issues: (1) sharing passwords; (2) sharing CDs. Since the idea was to let you listen to "your" CD anywhere you went, the method of verification could not be platform-specific; otherwise you would be tethered to the platform that did the verifying, unless you had multiple verifications on multiple platforms. So the password had to be capable of being used anywhere, and this mcant that you could give your password to someone else to use. Furthermore, since CDs did not have unique identifiers, it was impossible to verify ownership of an individual CD. Id. 
sometimes justify the copying of entire works and not just excerpts, brief or otherwise. ${ }^{33}$

A final group of fair use cases involves some harm to the copyright holder in lost revenues (and not because of criticism) but the harm is more than offset by the sum of the benefits to others and the savings in the transaction costs that would be incurred were licensing required. The Beanie Babies case illustrates this category also. Had PIL's collectors' guide consisted just of photographs of Beanie Babies, with no commentary, a fair use defense would clearly have failed because the harm to Ty would not have been offset by information benefits to potential collectors. ${ }^{34}$ The more substantial the contribution that the later author makes to the expressive domain by his use of copyrighted materials, the more likely that use is to be deemed a fair use. Courts call this type of use productive (or transformative) as distinct from simply reproductive (or superseding).$^{35} \mathrm{~A}$ productive use is one that lowers the cost of expression and thus tends to increase the number of original works, while a reproductive use simply increases the number of "copies" of a given work, reduces the author's profits, and so reduces the incentives to create new works. A fair use defense is more likely to prevail if the use is productive than if it is merely reproductive. Yet Sony found a merely reproductive use of the copyrighted work to be fair use; although time shifting has the potential to transform a reproductive use into one that actually benefits the copyright owner, it does not do so by adding to the work itself.

The "some harm" category is illustrated by cases involving unauthorized quotations from unpublished works, such as letters or a diary, often in a biography of the writer of the letters or diary. The convoluted history of the fair use defense in this setting is a story for another day. ${ }^{36}$ As the law seems finally to have shaken out, the courts will trade off the harm to the writer either from having his thunder stolen or from having his privacy invaded against the benefits to the biographer, historian, or journalist, and derivatively the reading public, from the fuller picture of the subject that quotation from his or her unpublished writings enables to be drawn. ${ }^{37}$

33. See also Sega Enters. Ltd. v. Accolade, Inc., 977 F.2d I5I0 (9th Cir. 1992).

34. In fact, as the court noted, the amount of commentary varied among the different collectors' guides that Ty claimed were infringing. Whether any or all contained enough commentary to come within the scope of the fair use defense was lcft for decision (subject of course to further appeal) by the district court on remand.

35. See, e.g., Campbcll v. Acuff-Rose Music, lnc., 5 I0 U.S. 569, 574 (1994); Harper \& Row Publishers, Inc. v. Nation Enterprises, 471 U.S. 539, 561 (1985); Sony Computer Entertainment, Inc. v. Connectix Corp., 203 F.3d 596, 606-08 (9th Cir. 2000); Nihon Keizai Shimbun, Inc. v. Comline Business Data, Inc., I66 F.3d 65, 72 (2d Cir. I999).

36. See Landes \& Posner, supra note 9, ch. 5; William F. PAtry, The Fair Use Privilege In COPYRIGHT LAW 3-63 (2d ed. 1995).

37. See Sundeman v. Seajay Society, Inc., I42 F.3d 194 (4th Cir. I998); Wright v. Warner Books, Inc., 953 F.2d 73 I (2d Cir. 1991); Norse v. Henry Holt \& Co., 847 F. Supp. 142 (N.D. Cal. I994). 


\section{Application to the Eldred Problem}

If we now apply the fair use doctrine as sketched above to the situations that concerned the petitioners in the Eldred case, we shall see that the defense is indeed capacious enough to accommodate their legitimate concerns. The key point is that it is not the amount copied that is determinative in the present context, although that is one of the optional statutory factors, but the feasibility of a market transaction. If transaction costs are low, it is better to have a clear definition of property rights, as that will facilitate transacting. But the condition is not satisfied in the situation in which the Eldred petitioners and those similarly situated find themselves, just as it is not satisfied in the "brief excerpts" situation that provides the clearest justification for the doctrine. Because by hypothesis the works in question are very old and of very limited commercial value, the cost in time and expense of obtaining a license may exceed the private value of the license even though the social value of publication might be substantial. ${ }^{38}$ It might be difficult or even impossible to track down the owner of the copyright, and if he were tracked down and asked for a license he might be so startled to learn that he had a property of potential value that he would refuse to license without consulting a lawyer or other expert, driving up the licensing cost.

It does not follow that the fair use privilege should be understood to permit the copying of all old works of limited value. That would fly in the face of the CTEA and of Eldred. The correct balance is struck, rather, by imposing a duty of reasonable inquiry on the would-be copier. The satisfaction of that duty would require him to determine, as by hiring a reputable service that specializes in tracing people ${ }^{39}$ whether the person indicated on the copyright page or in other records known to or readily available to the would-be copier as the owner of the copyright was, if an individual, still living, and, if a firm or other organization, still in existence. The would-be copier would be required to seek a license from that individual or entity unless the search, though properly conducted, had turned up nothing-had failed to discover a copyright owner from whom the would-be copier might try to negotiate a license-in which event the copying of the work would be deemed a fair use.

38. The social value is the sum of the producer and consumer surplus created by the work. The private value to the producer is of course just the producer surplus, which may be slight unless he can convert consumer to producer surplus. A monopolist can; a competitive firm cannot, and public-domain publishers lack even the limited monopoly power conferred by a copyright.

39. There are a number of Internet "missing person" search services, such as Peoplefind.com, Omnitrace.com, and Ussearch.com, that would enable one to find, for a fee of $\$ 10$ to $\$ 20$, a copyright holder's contact information on the Internet by entering the name and other identifying data such as an approximate age or geographic region. Omnitrace allows an individual, for $\$ 50$, to talk on the phone with a personal representative who will then conduct the search and call back onee the desired person is located. However, when nothing is known about a person except his or her name, and the name is a common one shared by thousands of people, the search process can be costly and time-consuming. 
A predictable consequence of such a rule (more precisely, of such an understanding of the fair use defense as applied to old copyrighted works) would be that an existing or new intellectual property organization would create a registry of copyright owners, or that the Register of Copyright would expand the official registry (on which more below) to include the type of notice that we envisage. There are analogies in the field of visual art. Both the Visual Artists and Galleries Association and the Artists Rights Society help people who want to reproduce works of art obtain licenses from the copyright holders. Each organization publishes a list of the artists it represents, keeps a slide catalogue of works of its members, and acts as the artists' agent in negotiating licenses for reproductions of their art. Were there a private copyright registry, or if the Register of Copyright expanded the official registry along the lines that we have indicated, anyone who owned a copyright would be free to list his name and address on the registry, and a search of the registry would be a prerequisite to the assertion of a fair use right to copy. ${ }^{40}$ The creation of a private registry (or the expansion by regulation of the official one) by way of response to the fair use privilege is an attractive alternative to requiring public registration (or rather re-registration, in any case where the copyright owner was different from the owner shown on the copyright page) of copyrights, since that would require legislation.

By way of a further limitation, the fair use right that we are proposing might be limited to works that are still under copyright only by virtue of the copyright's having been extended by the CTEA, and to copiers whose purpose is to enable public access to otherwise inaccessible works (such as books out of print) to the public. Anyone who lost his exclusive rights by virtue of invocation of the fair use doctrine would, as we pointed out earlier, be losing only a windfall.

The suggested rule is in keeping with the spirit of the advice to authors seeking permission provided by the authoritative Chicago Manual of Style:

The elements of a bona fide search [for a missing copyright owner] will vary with the circumstances but could well include a search of the Copyright Office records, an attempt to communicate with the copyright owner at whatever address is last stated in the file for the work concerned, and perhaps an Internet search for the author or publishers. If such efforts yield no results, there is still some risk in going forward. Technically, use of the work might still be ruled an infringement of copyright should a copyright owner surface, but it

40. The Copyright Office already maintains a Visual Artists Registry for works of visual art incorporated in or made a part of buildings in order to implement the moral-rights amendments to the Copyright Act. 37 C.F.R. $\$ 201.25$ (2003). See 17 U.S.C. $\$ 113(d)(1)(2001)$. 
is unlikely that any court would do more than require the payment of a reasonable permissions fee. ${ }^{41}$

Obviously some authors and publishers will not be reassured by this advice; they will want a legal safe harbor and that is what we suggest. ${ }^{42}$ Our suggested rule is narrow in scope and is consistent with the rationale of the fair use doctrine. It is also in keeping with the spirit of influential "Classroom Guidelines" negotiated by publishers, authors, and educators in 1976, which picking up the statement in section 107 of the Copyright Act that multiple copies of a copyrighted work for classroom use may be fair use requircs that "the copying must be so close to the time of need that permission may not be reasonably obtained.",43 In other words, prohibitive transaction costs may justify even the making of multiple copies of entire copyrighted works.

\section{A Possible Statutory Objection}

We need to consider the possible bearing of sections 302(d) and (e) of the Copyright Act on our suggested rule. Those rather complicated subsections, the thrust of which is to provide some relief for copiers of old works, state as follows:

(d) Records Relating to Death of Authors.-Any person having an interest in a copyright may at any time record in the Copyright Office a statement of the date of death of the author of the copyrighted work, or a statement that the author is still living on a particular date. The statement shall identify the person filing it, the nature of that person's interest, and the source of the information recorded, and shall comply in form and content with requirements that the Register of Copyrights shall prescribe by regulation. The Register shall maintain current records of information relating to the death of authors of copyrighted works, based on such recorded statements and, to the extent the Register considers practicable, on data contained in any of the records of the Copyright Office or in other reference sources.

(e) Presumption as to Author's Death.-After a period of 95 years from the year of first publication of a work, or a period of 120 years from the year of its creation, whichever expires first, any person who obtains from the Copyright Office a certified report that the records provided by subsection (d) disclose nothing to indicate that the author of the work is living, or died less than 70 years before, is entitled to the benefit of a presumption that the

41. Chicago Manual of Style 134 (15th ed. 2003).

42. The MANUAL notes that "many publishers tend to seek permission if they have the slightest doubt whether a particular use is fair." Id. at 137.

43. Kenneth D. Crews, Copyright, Fair Use, and the Challenge for Universities: Promoting the Progress of Higher Education 73 (1993) (citing H.R. Rep No. 1476, 94th Cong., 2d Sess. 68-71 (1976)). 
author has been dead for at least 70 years. Reliance in good faith upon this presumption shall be a complete defense to any action for infringement under this title. ${ }^{44}$

These provisions are a step in the right direction, but their scope is too limited to meet the need identified by the Eldred brief. For one thing, subsection (d) requires the maintenance only of records of authors' deaths ${ }^{45}$ and not records of authors who although they are alive may be untraceable or uninterested in the exploitation of their work. More important, the presumption of subsection (e) appears to be inapplicable to works made for hire, though we cannot find any cases or legislative history on the question. Most important, the presumption has no present application. Copyright on works published before 1923 and therefore copyrighted under the 1909 copyright act expired before 1998, because the Copyright Act of 1976 fixed the copyright term of works copyrighted under the 1909 act at 75 years (a 28-year initial term plus a 47 -year renewal term). ${ }^{46}$ Those works have thus been pitched into the public domain, and the presumption in section 302(e) has no application to works in the public domain; such works can be copied freely. For works first published between January 1, 1923, and December 31, 1977 (the last effective date of the 1909 act), the CTEA created a 95 -year term by extending the renewal term to 67 years. ${ }^{47}$ The earliest that any of these copyrights will expire is thus 2018, and some will not expire until the end of 2072. Works created in 1977 but not published until later may not go out of copyright until $2097 .{ }^{48}$ Until the copyright expires, the presumption in section 302(e) has no force.

But we must consider whether section 302(e), limited as it is as a solution to the problem of publishing old works, nevertheless preempts the use of the fair use doctrine to provide a fuller solution. We think not. Subsections (d) and (e) were enacted as part of the comprehensive revision of the copyright statute by the Copyright Act of 1976, but they had first been proposed in a 1963 preliminary draft bill done by the Copyright Office $^{49}$ and the fullest explanation of their purpose, as well as the explanation closest in time to the introduction of the subsections themselves, which took place in 1964 and 1965, is a 1965 report by the Copyright Office to Congress. There we read:

44. 17 U.S.C. § 302(d)-(e) (2000).

45. Regulations implementing this provision are still in preparation, although the Copyright Office formulated an interim rule in 1979. Copyrights, 158 Fed. Reg. 47550 (Aug. 14, 1979). In the meantime, the Office has accepted statements regarding an author's death. These statements are indexed under the names of the person filing the statement and the author. If a title of a work is given, it is also indexed and is searchable. See http://www.copyright.gov.

46. 17 U.S.C. $\$ 304$.

47. Id.

48. 17 U.S.C. $\$ 304$.

49. See Copyright Law Revision Part 3, Preliminary Draft for Revised U.S. Copyright Law and Discussions and Comments on the Draft § 20(d) (GPO Sept. 1964). 
Subsections (d) and (e) of section 302 are aimed at furnishing an answer to the most serious argument against a copyright term based on the life of the author: the difficulty, and in a number of cases the impossibility, of determining the date of death for lesser-known authors... Taken together we belicve that these two subsections would largely surmount the practical problems arising from a life-plus-50 term. ${ }^{50}$

Determining the date of death of an obscure author is indeed one of the problems that moving from a registration-and-renewal to a life-plus-termof-years rule creates. But it is far from being the only problem, and we cannot find any indication in the history of section 302 that Congress intended to limit the application of the fair use doctrine to the broader set of problems that has given rise to our proposal. Nor do we find any such indication in the structure of the section. It does not have the form of fair use analysis but instead creates a flat exemption based on satisfying specific criteria. And it does not place the burden of proof on the defendant, as in the case of fair use, which is an affirmative defense. We think it unlikely, therefore, that Congress meant by it to curtail the grant of judicial discretion in section 107-especially since the purpose of section 302(e) has been undermined by CTEA's addition of 20 years to the long copyright term created by the 1976 Act. ${ }^{51}$ Our modest proposal regarding fair use would if adopted, be conducive to achieving the goal of that section under the changed conditions that CTEA has brought about.

\section{III}

\section{Overclaiming AND COPYRIght Misuse}

The fly in the ointment is this: Copyright owners and their lawyers are likely to continue advising would-be copiers that they are infringers even when the proposed copy would be a fair use ${ }^{52}$; and the copiers will be reluctant to provoke litigation over the issue. The Copyright Society of the U.S.A. advises on its website that the copying even of just a few seconds of a movie or a television program is not fair use: "[i]f film clips or photographs from motion pictures, television programs, or other sources are used, consent is required from the copyright owner to use clips or photographs in a motion picture, no matter de minimis or short.."53 That is

50. House Comm. on the Judiciary, 89th Cong., Supplementary Report of the Register of Copyrights on the General Revision of the U.S. Copyright Law: 1965 Revision Bill 92 (Comm. Print 1965). As originally enacted in 1976, the figure of 70 years in section 302(e) was 50 years; it was changed to 70 by the CTEA. See CTEA, supra note 2 .

51. The CTEA added the 20 years to section 302(e) as well-that's the problem-but there is no indication that Congress realized the implications of this extension. In the section as originally enacted, the operative dates were 75 and 100 years.

52. See, e.g., Chicago Manual OF StYle, supra note 41.

53. The Copyright Society of the USA, at http://www.csusa.org/face/movim/faqs.htm\#props (last visited July 18, 2004). 
not the law, but the following true horror story suggests that the law may have only a limited practical significance in this area:

[W]hile interviewing students for a documentary about inner-city schools, a filmmaker accidentally captures a television playing in the background, in which you can just make out three seconds of an episode of "The Little Rascals." He can't include the interview in his film unless he gets permission from the copyright holder to use the three seconds of TV footage. After dozens of phone calls to The Hal Roach Studios, he is passed along to a company lawyer who tells him that he can include the fleeting glimpse of Alfalfa in his nonprofit film, but only if he's willing to pay $\$ 25,000$. He can't, and so he cuts the entire scene. ${ }^{54}$

The company lawyer was wrong. The three-second "quotation" from the copyrighted television show was a fair use. ${ }^{55}$ But the documentary filmmaker was not in a position to challenge the lawyer's tendentious "advice" at the risk of having his project enjoined or being made to pay statutory damages.

These examples can be multiplied at will. Recently the New York Review of Books published a newly discovered notebook entry by Virginia Woolf, and a note at the end of the article states: "Copyright (C) 2003 by the Estate of Virginia Woolf. No part of this text may be reproduced without the express prior consent of Hesperus Press." ${ }^{56}$ No part? That is ridiculous. A journalist, biographer, literary critic, or historian writing about Virginia Woolf would be entitled by the fair use doctrine to quote a brief passage from the article. The note is pure bluff, ${ }^{57}$ but a public-domain publisher threatened by a lawyer representing Hesperus Press with legal action would think twice about publishing even the briefest passage 12.

54. Jeffrey Rosen, Mouse Trap: Disney's Copyright Conquest, New Republic, Oct. 28, 2002, at

55. See Sandoval v. New Line Cinema Corp., 147 F.3d 215 (2d Cir. 1998); Meeropol v. Nizer, 560 F.2d 1061 (2d Cir. 1977); Woods v. Universal City Studios, 920 F. Supp. 62 (S.D.N.Y. 1996); Amsinck v. Columbia Pictures Indus., Inc., 862 F. Supp. 1044 (S.D.N.Y. 1994); Italian Book Corp. v. Am. Broad. Cos., 458 F. Supp. 65 (S.D.N.Y. 1978); Mura v. Columbia Broad. Sys., Inc., 245 F. Supp. 587 (S.D.N.Y. 1965); Patry, supra note 36 at 484; Pierre N. Leval, Nimmer Lecture: Fair Use Rescued, 44 UCLA L. REv. 1449, 1457 (1997). Ringgold v. Black Entm't Television, Inc., 126 F.3d 70 (2d Cir. 1997), which reversed a grant of summary judgment for the defendant in a case superficially much like the Little Rascals case, may seem to cut the other way. But it is distinguishable-the defendant used the plaintiff's cntire twenty-seven-second-long work of art as a prop in its program.

56. Virginia Woolf, At Lady Ottoline's, N.Y. Rev. BooKs, July 17, 2003, at 17. The entry was made in 1909.

57. These bluffs are sometimcs called, as when a manufacturer of vacuum cleaners refused Consumers Union's (CU) demand not to quote CU's favorable evaluation of the manufacturer's vacuum cleaner. $\mathrm{CU}$ then sued for copyright infringement and lost. Consumers Union, Inc. v. Gen. Signal Corp., 724 F.2d 1044, 1048-5l (2d Cir. 1983). See also Groucho Marx, The Groucho LETTERS: LeTters FROM AND to Groucho MARX 13-I8 (1967) (describing Groucho Marx's response to the attempt by Warner Brothers, which owned the copyright on the movic Casablanca, to prevent the Marx Brothers from using the word in their movie $A$ Night in Casablanca). 
without consent. Someone in Eldred's shoes would worry that if, even after exhaustive inquiry justified him in believing that there was no living owner of the copyright on a work that he wished to publish, a copyright owner should jump out of the woodwork and seek to enjoin publication, the ensuing legal struggle would cost more than it was worth. In Margaret Atwood's recent novel Oryx and Crake, the author thanks "John Calder Publications and Grove Atlantic for permission to quote eight words from Samuel Beckett's novel, Mercier and Camier." Atwood, a highly successful author, can afford to negotiate with two publishers for permission to quote eight words; other authors cannot; and in any event the time and expense required to make and process such a request are a social waste.

According to the copyright officer at one distinguished university press, the press presumes that if you come to them asking for permission to quote, the quoted material is not within the scope of fair use. But if the copyright officer senses that the person he's talking to is a complete novice-in his words, "blind and lame"-he will instruct him on the fair use privilege, but this does not happen very often.

The same press instructs its authors as follows with regard to fair use:

Permission is not required for brief excerpts quoted for the purpose of scholarly review or analysis or for supporting arguments. This is clearly "fair use." In determining whether a use is "fair," a number of factors must be considered, but extensive quotation from a chapter or article, or the reproduction of an illustration or a complete poem can rarely be considered "fair use." 59

This is somewhat vague, and very narrow. Another distinguished university press instructs its authors that

[I]n general, poetry requires permission when quoted for any purpose other than literary analysis or commentary.... You may quote from published prose works in copyright if you are making fair use of the work. How much is "fair" has never been spelled out, but usually you may quote up to 1,000 words from any book-length work of prose without specific permission as long as you acknowledge author, title, and publisher.... The number of quoted words considered fair use may be much smaller for a shorter published work (an article, short story, or letter, for instance). Do not use any complete unit, such as a case history,

58. Margaret Atwood, Oryx And Crake: A Novel. 375 (2003).

59. Editors Note: The authors' copy of these instructions was misplaced. California Law Review therefore could not verify this quotation. For publishers' policies with similar fair-use instructions, see supra note 62 . 
letter, or complete description, even if it is less than 1,000 words, without permission. ${ }^{60}$

Among the mistakes in the quoted passage are the implication that no quotations of poetry are fair use, the arbitrary 1000-word "safe harbor," the mistaken implication that copyright law requires acknowledgments of fair use copying, and the assertion that copying a "complete unit" can never be fair use. The impression conveyed is of a fair use privilege far narrower, and therefore a copyright owner's right far broader, than the law recognizes. Kenneth Crews's study similarly concludes that universities adopt guidelines for their faculty and librarians that are excessively conservative with regard to the fair use privilege. ${ }^{61}$

These examples could be multiplied indefinitely. ${ }^{62}$ Here is just one more. In a compilation of quotations and excerpts from the world's greatest "freethinkers," a book appropriately entitled Freedom: Quotes and Passages from the World's Greatest Freethinkers, by Leonard Ray Frank, published by Random House in 2003, the reader is warned: "No part of this book may be reproduced in any form or by any means, electronic or mechanical, including photocopying, without the written permission of the publisher"-this even though most of the book consists of writings over which the publisher has no rights at all.

60. Emphases in original. Editors Note: The authors misplaced their copy of these instructions. Califomia Law Review therefore could not verify this quotation. For publishers' policies with similar fair-use instructions, see infra note 62.

61. See CREws, supra note 43 , at 115.

62. Inquiry of a number of publishers yielded such gems as: Peter Lang Publishing considers fair use copying of poems to be limited to two lines, regardless of the poem's length, while the University of Virginia Press raises the limit to three lines and the Penn State University Press lowers it to one and also requires permission to copy "any words or music of a popular song." C/F International, Inc., claims to have challenged productions that used as little as three seconds of its copyrighted programming. Many publishers, such as Samuel French Ine. and Guilford Publications, forbid copying of any part of a copyrighted work without permission; that, of course, is a denial of the existence of the fair use privilege. A recent working paper of the National Bureau of Economic Research states: "Short seetions of text not to exceed two paragraphs, may be quoted without explicit permission provided that full credit, including $(O$ notice, is given to thc source." This again is a denial of the existence of the privilege; a copyright holder has no legal right to impose conditions on fair use copying. The Quarterly Review frankly states that "the meaning of 'fair use' is vague and hotly contested" and requires permission for quoting any portion, however small, absolutely or relatively, of copyrighted music, song lyrics, or poems. Or consider the warning in television broadcasts of major league baseball games, quoted in Siva Vaidhyanathan, Copyrights and Copywrongs: The Rise of Intellectual Property and How It Threatens Creativity 17 (2001): "No pictures, descriptions, or accounts of this game may be rebroadcast or retransmitted without the expressed, written consent of the office of the Commissioner of Major League Baseball." As Vaidhyanathan points out, there is no legal authority for forbidding a fan who is watching a broadcast of the game to send an account of it by e-mail to a friend. $l d$. Vanderbilt University Press refreshingly claims "to err on the side of fair use," yet still advises authors to quote no more than one or two lines from a short poem or four to six lines from a long one without seeking permission from the copyright owner. "Short" and "long" are not defined. 
The problem of overclaiming of copyright in situations in which asymmetrical stakes discourage a legal challenge to the claim ${ }^{63}$ argues strongly for a safe-harbor approach, which our proposal is. The copier who makes the good-faith inquiry prescribed by the proposal is protected against liability for infringement. There is precedent for judge-made safe harbors even in statutory cases. ${ }^{64}$

To deal with overclaiming of copyright, there is fortunately at hand the doctrine of copyright misuse, which "prevents copyright holders from leveraging their limited monopoly to allow them control of areas outside the monopoly." ${ }^{15}$ As reference to "leveraging" suggests, the doctrine, like its better-known cousin, the doctrine of patent misuse, ${ }^{66}$ has generally been applied to practices thought to be anticompetitive, such as certain tying arrangements. But it is not limited to such practices; if it were, it would simply duplicate antitrust law. As the Fourth Circuit said in the Lasercomb case, "[ $t]$ he question is not whether the copyright is being used in a manner violative of antitrust law (such as whether the licensing agreement is 'reasonable'), but whether copyright is being used in a manner violative of the public policy embodied in the grant of a copyright." ${ }^{.67}$

The doctrine of copyright misuse is thus applicable where litigation is threatened in an effort to extract a licensing fee or other profit when there is no reasonable basis for supposing that the threatener's copyright has been infringed. The intent and effect of such behavior are to give the copyright owner more legal protection than copyright law is designed to dowhich is a serviceable definition of copyright misuse. Compare Vogue Ring Creations, Inc. v. Hardman, which holds that a copyright warning that

63. For example, ASCAP demanded license fees from children's summer camps on the ground that singing copyrighted songs around the campfire is a public performance. A number of camps knuckled under before the public outcry caused ASCAP to abandon its demand. See Lisa Bannon, Birds Sing, But Campers Can't-Unless They Pay Up, STAR TRIB. (1996), available at http://www.law.umkc.edu/faculty/projects/ftrials/communieations/ASCAP.html; Ken Ringle, ASCAP Changes its Tune; Never Intended to Collect Fees for Scouts' Campfire Songs, Group Says, WASH. Post (1996), available at http://www.law.umkc.edu/faculty/projects/ftrials/communications/ ASCAP.html.

64. See, e.g., Herzberger v. Standard Ins. Co., 205 F.3d 327 (7th Cir. 2000); Miller v. McCalla, 214 F.3d 872, 876 (7th Cir. 2000); Bartlett v. Heibl, I 28 F.3d 497, 501-02 (7th Cir. 1997); United States v. Alston., 974 F.2d 1206, 1214-15 (9th Cir. 1992).

65. A\&M Records, Inc. v. Napster, Inc., 239 F.3d 1004, 1026 (9th Cir. 2001). See Alcatel USA, Inc. v. DGl Techs., Inc., 166 F.3d 772, $792-94$ (5th Cir. 1999); Practice Mgmt. Info. Corp. v. American Med. Ass'n., 121 F.3d 516, 520-21 (1997), amended, 133 F.3d 1140 (9th Cir. 1998); DSC Communications Corp. v. DGl Technologies, Inc., 81 F.3d 597, 601-02 (5th Cir. 1996); Lasercomb Ameriea, Inc. v. Reynolds, 911 F.2d 970, 976-78 (4th Cir. 1990).

66. See, e.g., Morton Salt Co. v. G.S. Suppiger, 314 U.S. 488 (1942); C.R. Bard, Inc. v. M3 Sys., Inc., 157 F.3d 1340, 1372 (Fed. Cir. 1998).

67. Lasercomb, 911 F.2d at 978. See also In re Napster, Inc., Copyright Litig., 191 F. Supp. 2d 1087, 1102-05 (N.D. Cal. 2002). The decision in Saturday Evening Post Co. v. Rumbleseat Press, Inc., 816 F.2d 1191, 1200 (7th Cir. 1987), is not to the contrary. All it holds is that if the basis of a claim of copyright misuse is an anticompetitive practice, the proper standard for adjudication is that supplied by antitrust principles. 
exaggerates the sanctions for a copyright violation is a form of copyright misuse ${ }^{68}$ Exaggerating the substantive rights of a copyright owner by denying in effect the fair use privilege, the sort of abuse illustrated by the Little Rascals and New York Review examples, seems an equally serious form of copyright overclaiming. ${ }^{69}$

The courts must be careful not to place copyright owners on a razor's edge, however, where a mistake in a copyright warning precludes enforcement of the copyright (at least until the warning is withdrawn), leading them out of an abundance of caution to underenforce their legitimate rights. But where the warning grossly and intentionally exaggerates the copyright holder's substantive or remedial rights, to the prejudice of publishers of public-domain works, the case for invoking the doctrine of copyright misuse seems to us compelling.

\section{IV}

\section{STATUTORY SOLUTIONS}

If the course of common law rulemaking is thought too slow or too fraught with uncertainty, or if placing the burden of proof on the fair use claimant is thought too great a deterrent in light of the asymmetry of stakes to which we have pointed, then serious consideration should be given to a statutory solution. Such a solution is usually more appropriate for problems facing a class of individuals, whereas the fair use defense is interpreted and applied on a case-by-case basis, though some rules have emerged, as we have seen, such as the right of a book reviewer to quote brief passages from the book under review, or of scholarly critics to quote from the work they are criticizing. Although copyright owners may be opposed to a solution such as rolling back sections 302(d) and (e) to their former scope (75 years from publication and 100 years from creation, rather than 95 and 120) and expanding those sections to cover works for hire and works by live though missing authors, their opposition is unlikely to be as tenacious as it would to amending the CTEA. Our solution does not create any right to copy commercially valuable copyrighted works, but only rights in old works that are difficult to trace precisely because they have little or no current commercial value.

Another possible solution is found in a bill introduced in the House of Representatives on June 25, $2003 .^{70}$ The core of the bill, H.R. 260I, section 3, amending section 306 of the Copyright Act, provides:

68. 410 F. Supp. 609, 616 (D.R.I. 1976).

69. $C f$. Ty, Inc. v. Publ'ns. Int'l. Ltd., 292 F.2d 5I2, 520 (7th Cir. 2000); Qad.inc. v. ALN Assocs., 770 F. Supp. 126I, 1266-67 (N.D. III. 1991), aff'd in part, dismissed in part, 974 F.2d 834 (7th Cir. 1992); Russ Berrie \& Co. v. Elsner, 482 F. Supp. 980,988 (S.D.N.Y. I980).

70. H.R. 2601, 108tb Cong. (1st Sess. 2003) (The bill has been referred to committee, see http:/thomas.Ioc.gov/cgi-bin/bdquery/z?dI08:HR02601:@@@X, last visited July 18, 2004). 
The Register of Copyrights shall charge a fee of \$1 for maintaining in force the copyright in any published United States work. The fee shall be due 50 years after the date of first publication or on December 31, 2004, whichever occurs later, and every 10 years thereafter until the end of the copyright term. Unless payment of the applicable maintenance fee is received in the Copyright Office on or before the date the fee is due or within a grace period of 6 months thereafter, the copyright shall expire as of the end of that grace period. ${ }^{71}$

Experience under the registration and renewal regime that preceded the switch to life plus 50 years in the Copyright Act of 1976 indicates that even a nominal "renewal" fee (the functional equivalent of the $\$ 1$ fee in H.R. 2601) clears out most copyrights, returning the copyrighted works to the public domain. ${ }^{72}$ The bill if enacted would thus go far toward achieving the objective that has impelled us to explore the boundaries of fair use.

There might seem to be no reason for the owners of valuable copyrights to object to H.R. 2061 (or owners of valueless ones, but they would be unlikely to play a role in the legislative process in any event, having little or nothing at stake), but this is too optimistic. They are bound to oppose any effort to "water down" copyright protection, fearing a slippery slope. They might object less to a bill that, rather than stripping copyright protection altogether from any copyrighted works, amended section 107 to make clear the legitimacy of a fair use defense configured along the lines that we have sketched in this article.

\section{CONCLUSION}

The challenge to the constitutionality of the Sonny Bono Copyright Term Extension Act failed. CTEA is law and if anything a precedent for future extensions that will prevent valuable copyrights, no matter how old, from falling into the public domain. Some, at least, of the unfortunate consequences of well-nigh perpetual copyright can, however, be mitigated without reopening the constitutional debate. One of these is the impact on publishers who wish to publish very old (but still copyrighted) works of limited or no commercial value (remember that some of these publishers are nonprofit). Because the works are very old, the costs of negotiating for a copyright license are high, but because the works have only limited commercial value, the income generated by publication is unlikely to cover those costs. A solution lies at hand, however, in the fair use doctrine, which is flexible enough to allow the copying of such works without having to obtain a copyright license, and which is not blocked by any provisions of existing copyright law. A statutory solution may also be possible. And our

71. H.R. 2601, 108th Cong. (1st Sess. 2003) at 6-7.

72. See the statistical analysis in LANDES \& POSNER, supra note 9, at ch. 8. 
analysis may have implications for other ways in which problems created by excessively long copyright terms can be solved without recourse to constitutional litigation. 
